\title{
American snout, Libytheana carinenta (Cramer) (Insecta: Lepidoptera: Nymphalidae: Libytheinae) ${ }^{1}$
}

Donald W. Hall and Jerry F. Butler ${ }^{2}$

\section{Introduction}

The American snout, Libytheana carinenta (Cramer), is a small, relatively dull colored butterfly that is named because of the pronounced elongation of its labial palpi into a prominent snout. The specific epithet, carinenta, from the Latin root "carin" presumably refers to the keel-shape of the snout.

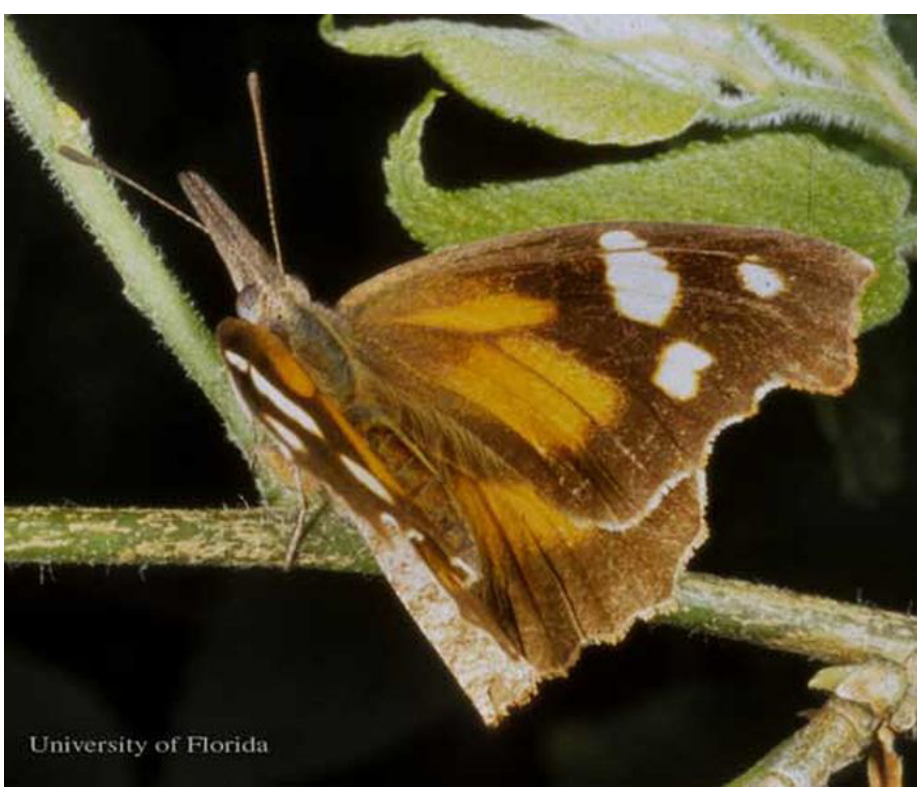

Figure 1. Dorsal view of the wings of an adult American snout, Libytheana carinenta (Cramer). (Hendricks County, Indiana; June 22, 2001).

Credits: Don Hall, University of Florida

\section{Synonomy}

Libytheana bachmanii (Kirtland) is a synonym of Libytheana carinenta (Cramer) (Heppner 2003).

\section{Distribution}

The American snout is found from southern and central California northeastward to Colorado and Nebraska and throughout most of the eastern U.S. It is common in northern and central Florida, but is infrequent in southern Florida. It also occurs through Central America and South America to Argentina (Minno et al. 2005, Opler et al. 2009).

\section{Description}

\section{Adults}

The wing spread of adults is 1.6 to 1.9 inches (Daniels 2003). The upper surface of the wings is blackish-brown with orange patches on the basal half of both fore and hind wings and white spots on the distal half of the forewings. The tip of the forewing is squared. The underside of the fore wings is similar to the upper side except the marginal areas may be lighter. The underside of the hind wings may be mottled or smooth purplish gray or brown.

There are a number of regional varieties that were once considered to be different species but are now considered to be subspecies of Libytheana carinenta. The eastern subspecies is L. c. bachmanii (Cech and Tudor 2005).

1. This document is EENY 452, one of a series of the Entomology and Nematology Department, UF/IFAS Extension. Original publication date June 2009. Revised September 2014. Visit the EDIS website at http://edis.ifas.ufl.edu.

2. Donald W. Hall, professor emeritus; and Jerry F. Butler, professor emeritus, Entomology and Nematology Department, UF/IFAS Extension, Gainesville, FL.

The Institute of Food and Agricultural Sciences (IFAS) is an Equal Opportunity Institution authorized to provide research, educational information and other services only to individuals and institutions that function with non-discrimination with respect to race, creed, color, religion, age, disability, sex, sexual orientation, marital status, national origin, political opinions or affiliations. For more information on obtaining other UF/IFAS Extension publications, contact your county's UF/IFAS Extension office. 


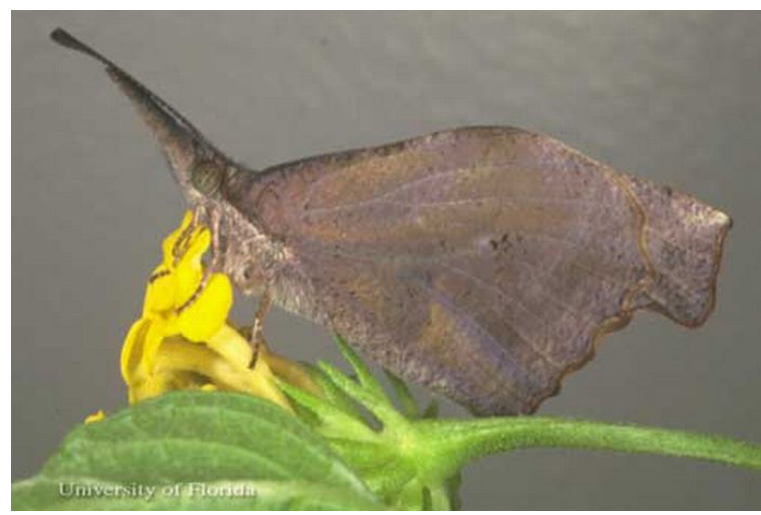

Figure 2. Ventral view of the wings of an adult American snout, Libytheana carinenta (Cramer).

Credits: Jerry Butler, University of Florida

\section{Eggs}

The eggs are pale yellow with the surface sculptured with a series of vertical ridges.

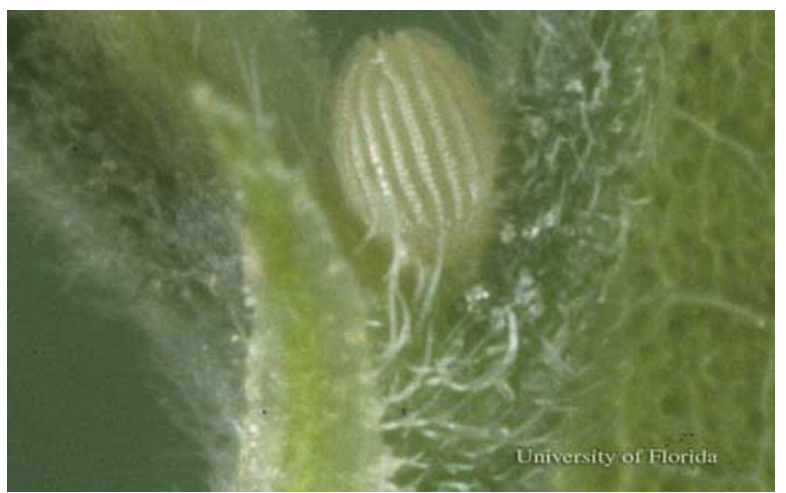

Figure 3. An egg of the American snout, Libytheana carinenta (Cramer), on sugarberry.

Credits: Jerry Butler, University of Florida

\section{Larvae}

Full grown larvae are approximately 1.0 inch in length. The head and body are green. The body has numerous small yellow dots and narrow yellow stripes on the back and sides (Minno et al. 2005). The first two thoracic segments are enlarged so that larvae appear to be hump-backed (Allen 1997, Opler and Krizek 1984). Larvae lack the prominent cephalic horns of the hackberry emperor, Asterocampa celtis [Boisduval \& Leconte], and the tawny emperor, Asterocampa clyton [Boisduval \& Leconte] — the other two common butterfly caterpillars on hackberries.

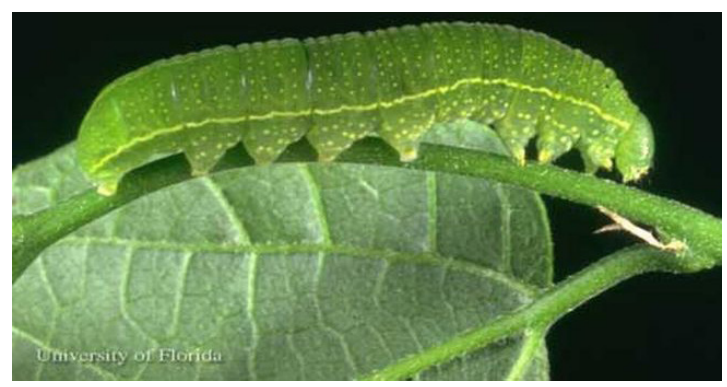

Figure 4. A larva of the American snout, Libytheana carinenta (Cramer). Credits: Jerry Butler, University of Florida

\section{Pupae}

The pupae are green with tiny white dots, a faint white line laterally on the abdomen and a prominent diagonal white line and two small points on the anterior end. The pupae are attached to a silk pad by the cremaster and hang vertically.

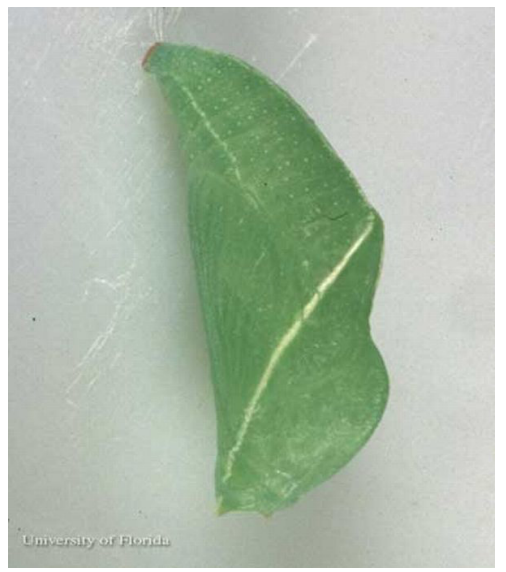

Figure 5. A pupa of the American snout, Libytheana carinenta (Cramer). Credits: Jerry Butler, University of Florida

\section{Life Cycle and Biology}

There are two generations per year throughout most of the range and three or more in Florida. Adults overwinter in the southern part of their range and repopulate more northern areas each spring. There are mass migrations northward in the West in some years with migrating butterflies numbering in the countless millions and said to darken the sky.

Males patrol in the area of the hackberry host plants to find females. Opler and Krizek (1984) state that mated pairs have only been observed at night. However, Scott (1986) states that mating appears to occur all day.

Adults feed on nectar from a wide variety of flowers (Allen 1997, Opler and Krizek 1984) with an apparent preference for white and yellow flowers (Kawahara \& Dirig 2006) and also commonly sip water and minerals from mud.

Eggs are laid singly (Minno et al. 2005) or in small clusters (Cech and Tudor 2005) in the leaf axils of young shoots or less frequently on young foliage or twigs. Larvae eat young foliage. When not feeding, larvae in Brazil are reported to rest on frass chains as a defense against predators (Freitas 1999).

In Florida, larvae may be found from March through early November. Larvae, pupae, and adults are all cryptically colored. Wagner (2005) has noted that larvae resemble partially opened leaves. Adults often rest on twigs with 
their dead-leaf mimic wings folded and the antennae and palpi aligned and angled down toward the twig so that they resemble the petiole of a dead leaf (Opler et al. 2009).

\section{Hosts}

The larval hosts of the American snout are hackberry trees (Celtis spp.) in the family Celtidaceae. The two most common hackberries in the eastern U.S. the more northern hackberry, Celtis occidentalis Linnaeus, and the more southern sugarberry, Celtis laevigata Willd., can usually be recognized by the slightly to heavily warty appearance of their trunks. More information and a key to the Celtis species is available at efloras.org (undated).

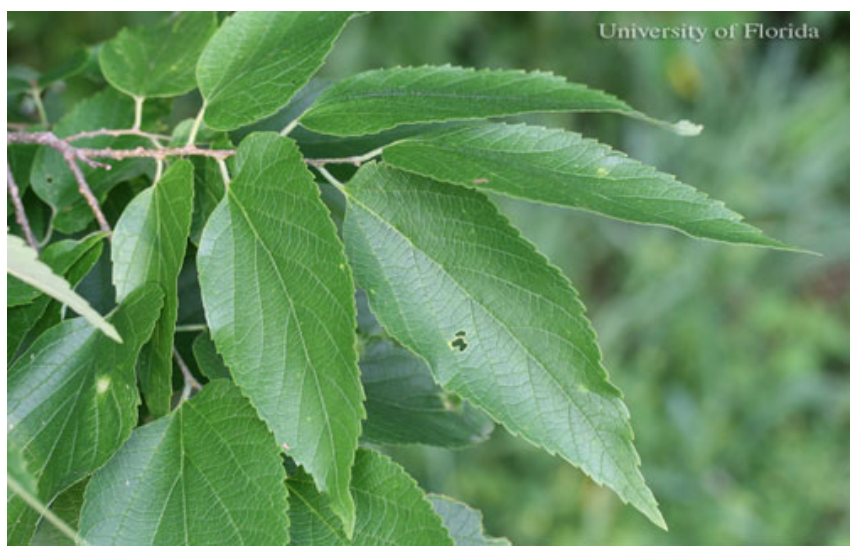

Figure 6. Hackberry, Celtis occidentalis L. (Celtidaceae), is a larval host for the American snout, Libytheana carinenta (Cramer).

Credits: Don Hall, University of Florida

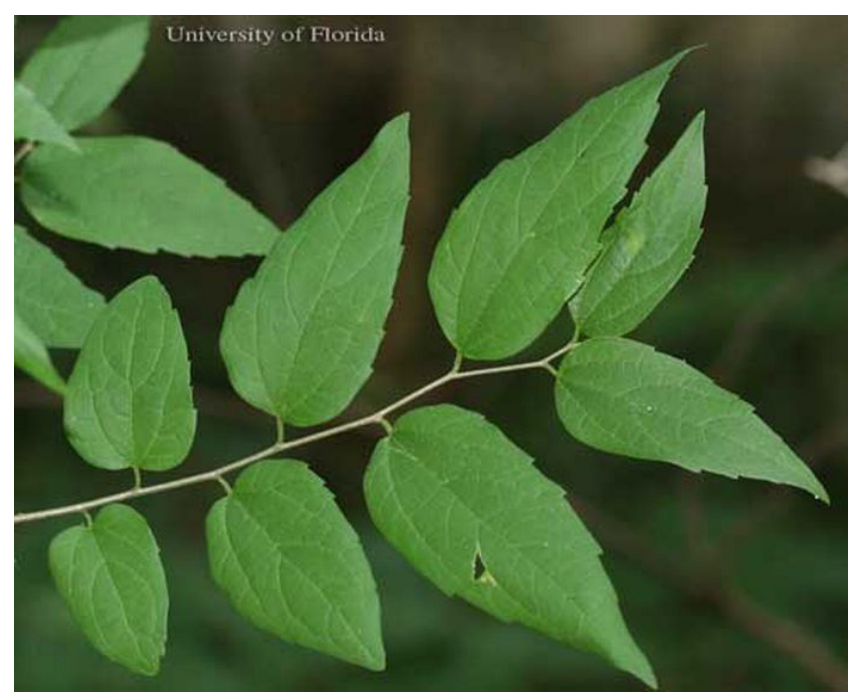

Figure 7. Sugarberry, Celtis laevigata Willd., a host of the American snout, Libytheana carinenta (Cramer).

Credits: Photograph by: Don Hall, University of Florida

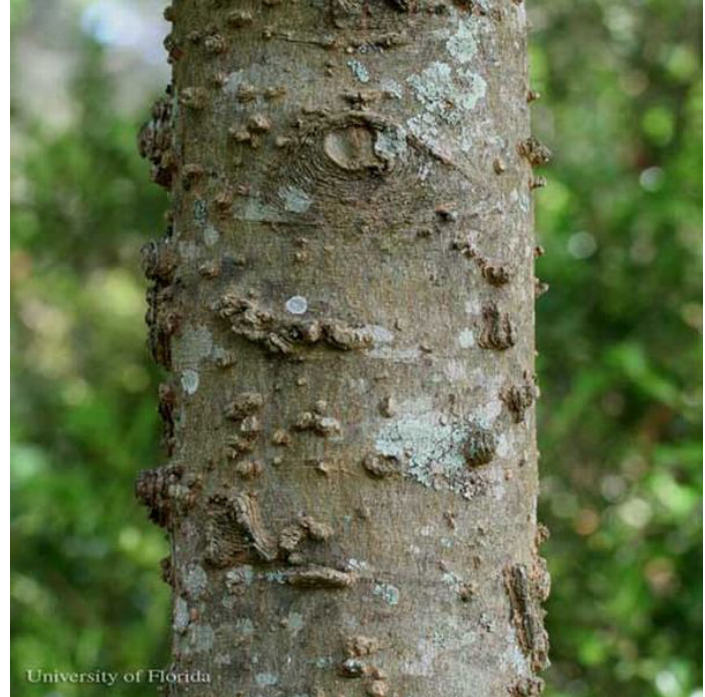

Figure 8. Warty trunk of the sugarberry, Celtis laevigata Willd., a host of the American snout, Libytheana carinenta (Cramer).

Credits: Don Hall, University of Florida

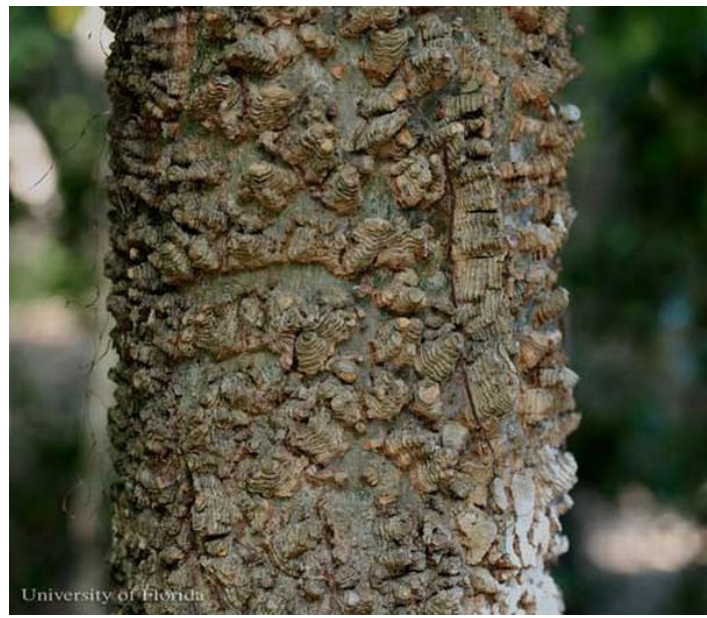

Figure 9. Heavily warty trunk of the sugarberry, Celtis laevigata Willd., a host of the American snout, Libytheana carinenta (Cramer). Credits: Don Hall, University of Florida

\section{Selected References}

Allen TJ. 1997. The Butterflies of West Virginia and their Caterpillars. University of Pittsburgh Press. Pittsburgh, Pennsylvania. 400 pp.

Cech R, Tudor G. 2005. Butterflies of the East Coast: An Observer's Guide. Princeton University Press. Princeton, New Jersey. 345 pp.

Daniels JC. 2003. Butterflies of Florida: Field Guide. Adventure Publications, Inc. Cambridge, Minnesota. 256 pp.Efloras.org. (undated). Celtis Linnaeus, Sp. Pl. 2: 1043. 1753; Gen. Pl. ed. 5, 467, 1754. Flora of North America. http://efloras.org/florataxon.aspx?flora_id=1\&taxon_ $\mathrm{id}=105995$ (11 May 2009). 
Freitas AVL. 1999(2000). An anti-predator behavior in larvae of Libytheana carinenta (Nymphalidae: Libytheinae). Journal of the Lepidopterists' Society 53(3): 130-131.

Heppner JB. 2003. Lepidoptera of Florida. Part 1. Introduction and Catalog. Volume 17 of Arthropods of Florida and Neighboring Land Areas. Division of Plant Industry. Florida Department of Agriculture and Consumer Services. Gainesville, Florida. 670 pp.

Kawahara AY, Dirig R. 2006. Nectar source records for Libytheana carinenta (Nymphalidae: Libytheinae). Journal of the Lepidopterists' Society 60(4): 233-237.

Minno MC, Butler JF, Hall DW. 2005. Florida Butterfly Caterpillars and their Host Plants. University Press of Florida. Gainesville, Florida. 341 pp.

Opler, PA, Lotts K, Naberhaus T. (2009). Butterflies and Moths of North America. http://www.butterfliesandmoths. org/ (12 May 2009).

Opler PA, Krizek GO. 1984. Butterflies East of the Great Plains. The Johns Hopkins University Press. Baltimore, Maryland. 294 pp.

Scott JA. 1986. The Butterflies of North America: A Natural History and Field Guide. Stanford University Press. Stanford, California. 583 pp.

Wagner DL. 2005. Caterpillars of Eastern North America. Princeton University Press. Princeton, New Jersey. 512 pp. 